\title{
施設入所後期高齢者を対象とした 足趾把持バー付きルームシューズの介入効果 \\ Intervention effects of rooms shoes with a toe-holding bar for the elderly aged 75 years or older living in a facility
}

\author{
阪本 昌志 ${ }^{1)}$, 村田 伸 ${ }^{2)}$, 中野 英樹 ${ }^{2)}$ \\ 松尾 大 $^{3)}$, 川口 道生 ${ }^{3)}$, 安彦 鉄平 ${ }^{2)}$ \\ Masashi Sakamoto ${ }^{1)}$, Shin Murata ${ }^{2)}$, Hideki Nakano ${ }^{2)}$ \\ Dai Matsuo ${ }^{3)}$, Michio Kawaguchi3 ${ }^{3)}$ Teppei Abiko ${ }^{2)}$ \\ 要旨：本研究は, 足趾把持バー付きルームシューズが施設入所後期高齢者の身体機能や歩 \\ 行能力に及ぼす効果を検討した。対象は施設入所後期高齢者 8 名であり，介入の効果検証 \\ にはベースライン期間（A）とそれに続く介入期間（B）を各 4 週間設定し，その測定值 \\ を比較する AB デザインを採用した。一般的なルームシューズで生活してもらったベース \\ ライン期間と比較し，介入後には歩行率の有意な向上と立脚期時間の短縮が認められ，歩 \\ 行速度が有意に高まった。これらの知見から，足趾把持バー付きルームシューズは，施設 \\ 入所後期高齢者の歩行能力を改善させる可能性が示された。 \\ キーワード：ルームシューズ, 歩行パラメータ, 施設入所後期高齢者

\begin{abstract}
The present study examined the effects of room shoes with a toe-holding bar on the physical function and walking ability of eight elderly aged 75 years or older living in an elderly facility. The elderly people were asked to wear general room shoes during the baseline period of four weeks (A) and room shoes with a toe-holding bar during the following intervention period of four weeks (B), and the measurements were compared to examine the effects of the intervention. There were significant increases in the gate rate and walking speed and a significant decrease in the stance phase time, compared with those in the baseline period. The results of the study suggest that room shoes with a toe-holding bar may improve the walking ability of the elderly aged 75 years or older living in a facil-
\end{abstract} \\ ity.
}

Key words: Room shoes, gait parameters, elderly aged 75 years or older, elderly facility

\footnotetext{
受付日：2019年 2 月18日，採択日：2019年 3 月16日

京都橘大学大学院健康科学研究科

Graduate School of Health Science, Kyoto Tachibana University

2) 京都橘大学健康科学部理学療法学科

Faculty of Health Science, Kyoto Tachibana University

3) アシックス商事株式会社

ASICS Trading Co., Ltd.

厂607-8175 京都市山科区大宅山田34

34 Ohyake yamada, Yamashina-ku, Kyoto-city, Kyoto 607-8175, Japan.

TEL : 075-571-1111 E-mail :.h901017005@tachibana-u.ac.jp
} 


\section{I 。背 景}

足趾・足底で地面を掴む力である足趾把持力は，短 母趾屈筋, 長母趾屈筋, 虫様筋, 短趾屈筋, 長趾屈筋 などの作用により起こる複合運動である1)。足趾把持 力と身体機能との関連を検討した先行研究では, 高齢 者の立位バランス ${ }^{2)}$ や転倒 ${ }^{3)}$ との関連が指摘されている。 また，足趾把持力が歩行速度や歩行率と有意な相関を 示すこと ${ }^{4}$, 歩行時の前方への推進力として作用する ことなどが報告 ${ }^{5,6}$ されている。このように，足趾把持 力は身体機能や歩行能力との関連が報告され, その重 要性が明らかとなっている。

足趾把持力は, トレーニングによって強化可能7で あり，その効果についてもいくつか報告されている。 村田ら ${ }^{8)}$ は, 足趾把持力トレーニングが転倒率を低下 させると報告し，また足趾把持力トレーニングが足趾 機能や歩行能力の向上に有効であることも報告 ${ }^{7-12)} さ$ れている。しかし，長期的なトレーニングの実施には， 環境的要因や心理的要因が関連するため, トレーニン グ効果を維持することは容易でない ${ }^{13,14}$ 。そこで村田 ら ${ }^{15)}$ は，足趾把持力トレーニング効果を継続させるた めに，足趾把持バーを取り付けたインソールを開発し た。若年者や健常な中高年女性を対象に, 足趾把持バー 付きインソールの効果を検証した先行研究16,17)では, 足趾把持バー付きインソールを運動靴に着用すること で，足趾把持力の向上が認められている。このように 特別なトレーニングを行うことなく，足趾把持力に効 果が認めたれたことは，転倒率の高い虚弱高齢者に対 する新たな介護支援になり得ることが期待される。た だし，高齢者施設に入所中の後期高齢者や虚弱高齢者 に着目すると，運動靴よりも軽量かつ着脱が容易な ルームシューズを履いている場合が多い ${ }^{18)}$ 。

そこで本研究は, 足趾把持バー付きルームシューズ が施設入所後期高歯令者の身体機能や歩行能力に及ぼす 効果を介入研究によって検討することを目的とした。

\section{II. 対象と方法}

\section{1. 対 象}

対象は京都市にあるA有料老人ホームに入居してい る後期高齢者に募集をかけ，研究協力が得られた 25 名 を対象とした。分析対象は，体調不良により途中脱落 した者，および久損值のある者を除外した 8 名である。 対象者はすべて女性であり，平均年齢86.6 6 5. 6歳 $(79$ ～95歳), 平均身長 $146.3 \pm 6.4 \mathrm{~cm}$, 平均体重 $49.1 \pm 7.4$ kg であった。また, 重度の認知症が認められる者 (Mini -Mental State Examination；MMSEで20点以下）は いなかった。各対象者には，研究の趣旨と内容につい て説明し，理解を得た上で協力を求めた。また，研究 への参加は自由意思であることを口頭と書面で説明し 参加の同意を得た。なお, 本研究は著者所属大学研究 倫理委員会の承認（承認番号17-11）を得て行った。

\section{2.ルームシューズの構造と機能}

ルームシューズの特徴は, 足先部の立体メッシュ構 造と第一趾から第五趾の基節骨中央付近に設けた凸形 状の盛り上がり構造（足趾把持バー）である（図 1 ）。 この足趾把持バーを装着して歩行すると, ターミナル スタンスにおいて足先部の合成繊維（立体メッシュ） が足趾にかかる荷重で沈み込み，基節骨の中央付近に 設けた足趾把持バーを足趾が認知して，足趾把持運動 を促進させる構造とした。

\section{3. 方 法}

測定項目は，身体機能評価として足趾把持力，30秒 椅子立ち上がりテスト（以下，30-sec chair stand test; CS-30）を測定し, 歩行能力評価として歩行パラメー 夕の測定を行った。

足趾把持力の測定 ${ }^{19)}$ には, 足趾筋力測定器（竹井機 器工業社製）を使用した。測定肢位は端座位とし，体 幹垂直位，股関節90度，膝関節90度屈曲位で実施した。 上肢は胸の前で組ませ，左右 2 回ずつ測定し，左右の
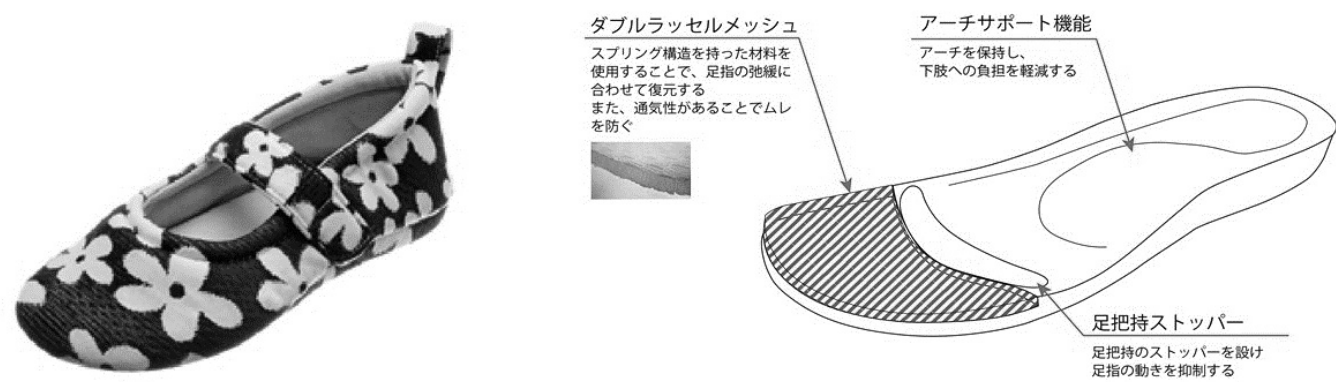

図 1 ルームシューズの構造 
最大值の平均を代表値とした。

CS - 30の測定 ${ }^{20}$ は, 肘掛けのない高さ $40 \mathrm{~cm}$ の椅子 を使用し，両上肢を胸の前に組んだ椅子座位にて実施 した。椅子座位から膝関節が完全伸展する立位となり， 再び着座するまでを 1 回とし，30秒間における合計回 数を計測した。

歩行パラメータは, 光学式歩行分析装置 (Microgate 社製 OPTOGAIT）を用いて測定した。OPTOGAIT は 2 本 1 対のバーに高さ $3 \mathrm{~mm}$ の高感度光学センサー が搭載されており，バーから得られる信号によって, 歩行パラメータの分析が可能である。本研究では, 距 離因子（ステップ長，ストライド長）, 速度因子（歩 行速度), 時間因子（立脚期時間，遊脚期時間，両脚 支持時間), 歩行率を測定項目とした。なお，歩行時 には「普段と同じ速さで歩いてください」と口頭で指 示し，測定中のシューズによる影響を避けるために裸 足で実施した。

\section{4. 介入手順}

本研究は、ベースライン期間（A）とそれに続く介 入期間（B）を設定し，その測定值を比較する $\mathrm{AB}$ デ ザインを採用した。ベースライン期間では，対象者が 普段履きなれている一般的なルームシューズで生活し てもらった。介入期間では, 対象者は足趾把持バー付
きルームシューズを着用し，通常と同じように生活す るよう指示した。なお，研究期間全体を通して施設内 の移動を制限することはしなかった。ベースライン期 間と介入期間は各 4 週間とし, 測定はベースライン開 始時（Pre 1), ベースライン終了時および介入開始 時（Pre 2 ），介入終了時（Post）の 3 回実施した（図 $2)$ 。

\section{5. 統計学的解析法}

各測定項目の統計処理は, 反復測定分散分析を行い 有意差を認めた場合，Bonferroni 法にて多重比較検定 を行った。なお，解析にはIBM SPSS Statistics 22を 用い，統計学的有意水準は $5 \%$ とした。

\section{III. 結 果}

反復測定分散分析の結果, 歩行速度 $(\mathrm{F}=6.18, \mathrm{p}$ $<0.05)$, 歩行率 $(\mathrm{F}=6.41, \mathrm{p}<0.05)$ ，立脚期時間 $(\mathrm{F}=7.27, \mathrm{p}<0.05)$ に有意な群間差を認めた。さ らに，多重比較検定の結果，歩行速度と歩行率はPre 2 と比較して, Postで有意な増加を示した $(\mathrm{p}<0.05)$ 。 また，立脚期時間はPre 1 と Pre 2 と比較して，Post で有意な短縮を示した $(\mathrm{p}<0.05)$ 。一方，足趾把持 力と CS - 30，拉よびステップ長・ストライド長・遊 脚期時間・両脚支持時間などの歩行パラメータには有

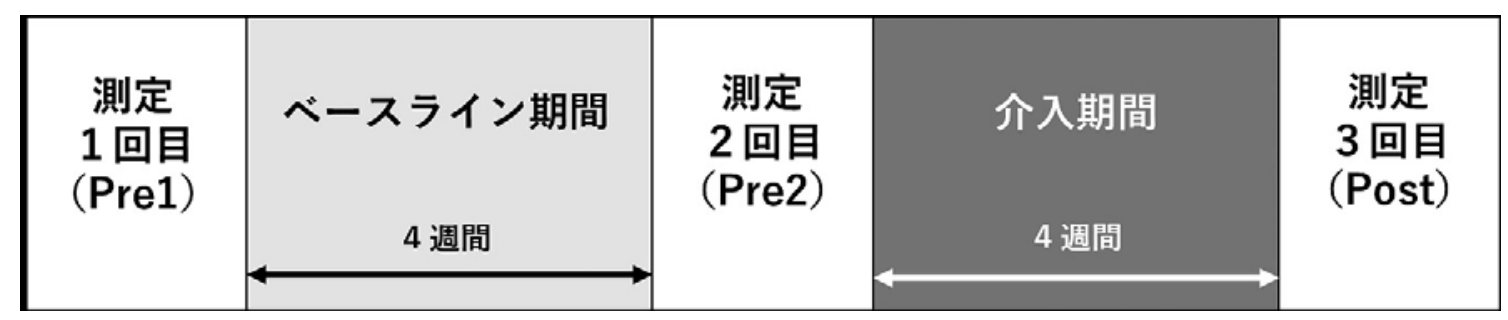

図 2 本研究の介入手順

表 1 身体機能ならびに歩行パラメータの変化 $(\mathrm{n}=8)$

\begin{tabular}{lccccc}
\hline & Pre 1 & Pre 2 & Post & F 值 & \\
\hline 足趾把持力 $(\mathrm{kg})$ & $3.16 \pm 2.64$ & $3.04 \pm 2.89$ & $2.64 \pm 2.74$ & 2.84 & \\
CS-30 (回) & $7.63 \pm 3.25$ & $8.13 \pm 3.76$ & $7.25 \pm 3.33$ & 0.92 & \\
ステップ長 $(\mathrm{cm})$ & $54.86 \pm 12.60$ & $51.01 \pm 16.61$ & $52.56 \pm 19.19$ & 0.88 & \\
ストライド長 $(\mathrm{cm})$ & $107.08 \pm 25.14$ & $101.19 \pm 33.26$ & $104.61 \pm 37.61$ & 0.58 & \\
歩行速度 $(\mathrm{m} / \mathrm{sec})$ & $0.58 \pm 0.32$ & $0.59 \pm 0.28$ & $0.81 \pm 0.38$ & $6.18^{*}$ & Pre $2<$ Post* $^{*}$ \\
立脚期時間 $(\mathrm{sec})$ & $1.02 \pm 0.43$ & $0.95 \pm 0.40$ & $0.77 \pm 0.45$ & $7.27^{*}$ & Pre1,2>Post* \\
遊脚期時間 $(\mathrm{sec})$ & $0.22 \pm 0.20$ & $0.23 \pm 0.19$ & $0.16 \pm 0.18$ & 1.65 & \\
両脚支持時間 $(\mathrm{sec})$ & $0.22 \pm 0.27$ & $0.25 \pm 0.17$ & $0.15 \pm 0.13$ & 1.41 & \\
歩行率 $(\mathrm{step} / \mathrm{min})$ & $68.97 \pm 35.71$ & $81.51 \pm 45.11$ & $115.19 \pm 66.49$ & $6.41^{*}$ & Pre $2<$ Post* \\
\hline
\end{tabular}

平均土標準偏差 ns: not significant

${ }^{*} \mathrm{p}<0.05$

反復測定分散分析，多重比較：Boneferroni 法 
意差は認められなかった（表 1 )。

\section{IV. 考 察}

本研究では, 足趾把持バー付きルームシューズが施 設入所後期高齢者の身体機能や歩行能力に及ぼす効果 を検証した。 4 週間の介入の結果，立脚期時間が有意 に短縮し, 歩行速度と歩行率が有意に増加した。この ことから，足趾把持バー付きルームシューズは，施設 入所後期高齢者の歩行能力を改善させる可能性が示さ れた。

歩行速度は, ステップ長と歩行率の積で表される ${ }^{21)}$ ことから, 歩行速度増加には, ステップ長と歩行率の どちらか, または両方の増加が必要であり, 立脚・遊 脚期時間の短縮に伴い歩行速度は増加する ${ }^{22)}$ 。本研究 では, 歩行率の有意な増加と立脚期時間の短縮が認め られた一方で，ステップ長やストライド長に有意差は 認められなかった。市橋 ${ }^{23}$ は, 高齢者では歩行速度の 増加に伴う歩行パラメータの変化は, ステップ長より も歩行率を増加させる傾向があると述べており，本研 究で対象とした施設入所後期高齢者にも同様の傾向が 認められた。

小澤ら ${ }^{24}$ は，健常成人を対象に歩行速度と時間因子 の関連について検討し, 歩行速度増加には, 立脚期時 間と両脚支持時間の短縮が大きな影響を与えると報告 している。本研究では, 立脚期時間は有意差が認めら れたが，両脚支持時間については，有意差が認められ なかった。健常成人よりも下肢筋力やバランス能力が 低下している高齢者では, 歩行時の安定性を得るため に，無意識に両脚支持時間をある一定の範囲内に確保 することが先行研究 ${ }^{25}$ より指摘されている。したがっ て, 施設入所後期高齢者を対象とした本研究では, 両 脚支持時間よりも立脚期時間を短縮させることが, 歩 行速度向上により影響を及ぼしたものと考えられた。

また，足趾把持力と CS-30においても介入効果は認 められなかった。村田ら ${ }^{8}$ の研究によると, 在宅障害 高齢者を対象に12週間の足趾把持トレーニングを実施 した結果，足趾把持力や歩行速度の改善が認められて いる。また, Nakano ら ${ }^{16,177}$ は, 若年者や健常な中高 年女性を対象に, 足趾把持バー付きインソールを装着 した靴を 4 週間使用した結果，足趾把持力が有意に向 上したことを報告している。本研究で足趾把持力に有 意差が認められなかった理由として, 対象が若年者や 在宅高齢者よりも活動量の少ない施設入所後期高齢者 であり，4 週間という短い介入期間では，足趾把持力
の向上までには至らなかったと考えられる。なお，CS -30は下肢筋力の評価指標として用いられる ${ }^{20,26)}$ が，足 趾把持トレーニングの効果を検討した研究影において, 大腿四頭筋力の強化は認められていない。今回の結果 は，先行研究と矛盾せず，下肢筋力においても介入前 後に大きく変化しなかったものと考えられた。

これらの知見から，足趾把持バー付きルームシュー ズは，施設入所後期高齢者の歩行能力を改善させる可 能性が示された。ただし，本研究は対象者数が少なく， 介入期間が短かったことから，今回の結果が他施設の 入所高齢者にも該当するとは限らない。また，介入時 間を統制できなかった点や，介入を行わない対照群の 設定が行えていないことなどが本研究の課題として挙 げられる。今後は，対象者数を増やし，ランダム化比 較試験を用いることに加えて, 測定項目を再考した上 で，より長期間の介入効果を検証する必要がある。

\section{引用文献}

1）村田 伸, 忽那龍雄：在宅障害者の足把持力と転倒との関 連性. 国立大学理学療法士学会誌, 2003, 24: 8 - 13 .

2）新井智之, 藤田博曉, 細井俊希 - 他 : 地域在住高齢者にお ける足趾把持力の年齢, 性別および運動機能との関連. 理 学療法学, 2011, 38(7)：489-496.

3）村田 伸, 津田 彰, 稲谷ふ久枝 -他：在宅障害高齢者の 転倒に影響を及ぼす身体及び認知的要因。理学療法学, 2005, 32(2) : 88-95

4）大杉紘徳, 村田 伸, 堀江 淳 - 他：地域在住高齢者の各 種歩行パラメー夕に関連する要因分析。ヘルスプロモー ション理学療法研究, 2014, 4 (1) : 31-35.

5）村田 伸, 忽那龍雄：在宅障害高齢者に対する転倒予防対 策一足把持力トレーニングー，日本在宅ケア学会誌，2004， $7(2): 67-74$.

6）相馬正之：歩行時の Toe clearance と足趾把持力について ヘルスプロモーション理学療法研究, 2016，6 (1)：1-7.

7) 竹井和人, 村田 伸, 甲斐義浩・他: 足把持力トレーニン グの効果. 理学療法科学, 2011, 26(1)：79-81.

8）村田 伸, 津田 彰：在宅障害後期高齢者に対する足把持 カトレーニングの転倒予防効果. 健康支援，2005， 7 (1)： 11-18.

9）福田 泉, 小林量作：若年健常者に対する足把持筋力下 レーニングの効果. 理学療法学, 2008, 35(5)：261-266

10）村田 伸, 大山美智江, 大田尾浩 -他：地域在住女性高齢 者の開眼片足立ち保持時間と身体機能との関連．理学療法 科学, 2008, 23(1): 79-83.

11）金子 諒, 藤澤真平, 佐々木誠：足趾把持筋力トレーニン グが最大速度歩行時の床反力に及ほす影響。理学療法科学、 2009, 24(3) : 411-416.

12）相馬正之, 五十嵐健文, 工藤 渉・他：足指把持力トレー ニングが Functional Reach Testや最大 1 歩幅, 歩行能力 に与える影響について。ヘルスプロモーション理学療法研 
究, 2012, 2 (2) : 59-63.

13) Dishman RK, Sallis JF, Orenstein DR: The determinants and interventions for physical activity and exercise. Public Health Rep, 1985, 100(2): 158-171.

14) Trost SG, Owen N, Bauman AE, et al.: Correlates of adults' participation in physical activity: review and update. Medicine \& Science in Sports \& Exercise, 2002, 34(12): 1996-2001.

15）村田 伸, 安彦鉄平, 中野英樹 - 他：足趾把持機能を高め るインソール（靴の中敷き）の開発.ヘルスプロモーショ ン理学療法研究, 2016, 6 (3) : 129-133.

16) Nakano H, Murata $S$, Abiko $T$ et al :Effect of Insoles with a Toe-Grip Bar on Toe Function and Standing Balance in Healthy Young Women: A Randomized Controlled Trial. Rehabilitation Research and Practice, 2017, 2941095.

17) Nakano H, Murata S, Abiko T et al :Effect of insoles with a toe-grip bar on toe-grip strength and body sway in middleaged and elderly women: Topics in Geriatric Rehabilitation, 2018 , in press.

18）三石清子, 宮地文子, 高橋勝貞 - 他 : 長野県東信地域の通 所施設に扔ける高齢者の足のトラブルに関する実態調査. 佐久大学看護研究雑誌, 2013, 5 (1) : 21-29.

19）相馬正之, 村田 伸, 甲斐義浩 - 他：足趾把持力発揮時に おける下腿筋の筋活動. 理学療法科学, 2013, 28(4)：491 -494 .

20) Jones CJ, Roberta ER, William CB, et al: A 30-s chair-stand test as a measure of lower body strength in communityresiding older adults. Res Q Exerc Sport, 1999, 70(2): 113119 .

21）大杉紘德, 美和香葉子, 重森健太 : 健常成人の後方歩行の 特徵。理学療法科学, 2007, 22(2)：199-203

22) Perry J, Burnfield JM：ペリー歩行分析正常歩行と異常歩 行. 医歯薬出版株式会社, 東京, 2012，323-329.

23）市橋則明：運動療法学第 2 版. 文光堂, 東京, 2015, 502515.

24）小澤実奈, 村田 伸, 空場勝之 - 他 : 最適歩行と最速歩行 中の歩行パラメーターと下肢筋活動の比較. ヘルスプロ モーション理学療法研究, 2016, 5 (4) : 179-183.

25）吴 婷琦, 渡部和彦：高齢女性における各種の強調歩行が 歩行動作に及ぼす影響：歩行速度, 足底圧力, 足部動作の 変化に着目して。体育学研究，2005，50(6)：651-661.

26）中谷敏昭, 灘本雅一, 三村寛一 - 他 : 日本人高齢者の下肢 筋力を簡便に評価する 30 秒椅子立ち上がりテストの妥当性. 体育学研究, 2002, 47: 451-461. 